\title{
ПОНЯТТЯ ВІДСУТНІСТЬ ЯК ЛІНГВОКОГНІТИВНА КАТЕГОРІЯ: РЕПРЕЗЕНТАЦІЯ В МОВНІЙ СИСТЕМІ
}

\author{
(Радчук О. В. Лингвокогнитивная репрезентация понятия «от- \\ сутствие» в русском языке. Харьков: Юрайт, 2019. 288 с.)
}

Серед базових абстрактних понять, долучених до формування концептуальної картини людини й спільноти, належить «відсутність» як компонент опозиційної онтологійної дихотомії «присутність - відсутність». У вимірі цієї дихотомії відбувається виокремлення тих об’єктів буття, що є обов'язковими для людини, натомість їхня відсутність усвідомлюється як руйнація упорядкованості й цілісності, загроза гармонійному перебігу життя. Лінгвістичний аналіз цього важливого поняття в проекції на когнітивні аспекти його вербальної репрезентації відповідає потребам сучасної лінгвістики щодо вивчення й опису різнорівневих мовних одиниць як засобів внутрішньої категоризації онтологійно важливих сутностей. Свого часу Олена Кубрякова визначила вектор когнітивних досліджень у лінгвістиці установкою на те, що мову варто вивчати «не лише як унікальний об’єкт, який розглядається в ізоляції, але значною мірою і як засіб доступу до всіх ментальних процесів, що відбуваються в голові людини й визначають її власне буття й функціонування в суспільстві» (Кубрякова, 2004: 9). Саме в таких дослідницьких стратегіях і перебуває лінгвістика XXI століття, дедалі глибше занурюючись у ментальні аннали мовного освоєння людиною дійсності.

3 огляду на цю наукову спрямованість проблематика рецензованої монографії $є$ актуальною для сьогочасся, оскільки ії авторка прагне розв'язати низку завдань, що допоможуть сформувати цілісну лінгвокогнітивну модель репрезентації поняття «відсутність» («отсутствие») у діахронійно-синхронійному вимірі російської мови для реконструкції російської концептуальної картини світу. До окреслених завдань належать і загальні теоретико-методологічні, і конкретні, пов'язані з етимологічним, лексико-семантичним, дериваційним, граматичним рівнями мовної експлікації поняття «відсутність».

Теоретико-методологічна платформа рецензованої монографії представлена у двох перших розділах. Науковим опертям здійсненого 
дослідження стали праці вітчизняних і зарубіжних мовознавців від О. Потебні до сучасників, серед яких особливе місце в розробці потрібної методології посіли теорії Ч. Філмора, Дж. Лакоффа, О. Кубрякової, А. Кошелева, ідеї С. Жаботинської, І. Мельчука та інших. Авторка монографії представила й власний алгоритм лінгвокогнітивної реконструкції досліджуваного поняття. До речі, аргументація вибору саме цього терміна в реєстрі лінгвокогнітивних засобів представлена О. Радчук цілком переконливо, адже поняття на противагу концепту є більш універсальним щодо термінологічної семантики, апелюючи до когнітивних площин людської свідомості, натомість концепт є складником суто концептуального простору, вужчого за когнітивний (Радчук, 2019: 22-23). Тож обрана дослідницею когнітивна царина цілком логічно корелює з терміном поняття, яке виявилося релевантним і продуктивним для розв'язання поставлених у роботі завдань. Імпонує, що дисертантка поділяє погляди тих учених, які наважуються екстраполювати в лінгвістичний дискурс різноманітні, зокрема й міждисциплінарні методики аналізу мови як біологічного, психоментального, культурного й суспільного феномену. Залучення даних цих наук до механізму лінгвістичного аналізу підвищує статус поняття як когнітивного терміна.

Як було зазначено, подане дослідження апелює до діахронійних аспектів питання (історичний вимір) і виходить на синхронію (різноманіття сучасних форм експлікації поняття «відсутність»у російській мові). У межах діахронії авторка підтверджує генетичний зв'язок опозитів «присутність» - «відсутність», описує репрезентацію поняття «відсутність» у довербальній і невербальній комунікації, зосереджується на пареміях як лінгвокультурному матеріалі для вивчення ціннісних орієнтацій етносу як носія відповідної колективної свідомості (розділ 3). Проведений аналіз засвідчив, що найбільш частотними $є$ синкретичні способи вербального вираження досліджуваного поняття в пареміях, за ним - морфологічні способи, за тим - лексико-семантичні. Найменш задіяний у репрезентації відсутності в російських паремійних зразках - синтаксичний спосіб. На думку авторки, це свідчить про те, «що синтаксична модель завдяки лексичному наповненню й морфологічним типам, що входять до її складу, посилює й підкреслює поняття «відсутність» у пареміях» (Радчук, 2019: 122). При цьому семантика речення-паремії (зазвичай 
односкладного) обмежує його структуру, тож граматичних ознак стає недостатньо для виокремлення цієї моделі як формального експлікатора поняття «відсутність». Цілком погоджуємося із цим висновком.

Особливості лексико-семантичної й дериваційної експлікації в лінгвальних репрезентаціях досліджуваного поняття прокоментовані в 4-му розділі монографії. Зокрема, О. Радчук звернула увагу на семантичні кореляції поняття «відсутність» 3 поняттями «порожнеча» («пустота») й «заперечення» («отрицание»), вивела їх на семантичну вісь перехідності й виявила залежність їхньої співвіднесеності від матеріальних репрезентантів. Дослідивши мовні референти обраного поняття, авторка дійшла висновків, що наявні в російській мові прототипи поняття «відсутність» нет і без розвинулися в нові номінації з подібною семантикою; але не завжди номінації будуть заново створюватися для вираження семантики відсутності, такі слова можуть запозичуватися й з інших мов (Радчук, 2019: 176). Щодо лексико-граматичних моделей репрезентації поняття «відсутність», то важливу роль у цьому відіграє префіксальна експлікація, яка впливає не лише на активізацію семи вiдcymність, але й подекуди ії втрату (подвійна префіксація) й порушення механізму репрезентації сем наявність і відсутність у формуванні значень слів. Слушною видається теза дослідниці про формування семантики еквівалентних ад’єктивів у російській та українській мовах (безопасний - безпечний), що відбувається в різний спосіб і різними шляхами, підтверджуючи цим автентичність кожної з мов (Радчук, 2019: 178).

Цікавить авторку й проблема «відсутність» у граматичній системі, чому присвячено розділ 5 монографії. Для реалізації поставлених у цьому розділі завдань й отримання переконливих результатів О. Радчук провела асоціативний експеримент, що допоміг об'єктивно поглянути на явище граматичної лакунарності як вияву поняття «відсутність» у російській мові. Семантичними типами цього поняття в граматиці є такі: повна відсутність (полное отсутствие) граматичних форм і явищ; заповнювана відсутність (восполняемое отсутствие) граматичних категорій (заповнена системою певна лакуна); зникнення (исчезновение) певних граматичних форм у процесі історичного розвитку (Радчук, 2019: 190). Одним зі способів експлікації поняття «відсутність», на переконання авторки, є суплетивізм як результат розвитку мови й відбиття ментальності ії носіїв. У роботі 
представлені тези відомих лінгвістів щодо явища суплетивізму в мові, надані власні аргументи на користь цих положень, однак, на нашу думку, наведені ілюстративні приклади (мовні одиниці) не завжди співвідносяться 3 поняттям «відсутність» (принаймні, ці приклади мають бути прозорішими й переконливішими для підтвердження висловлених міркувань щодо суплетивізму в лінгвальній репрезентації поняття «відсутність»).

$€$ ще одне міркування зауважувального характеру, що виникло внаслідок ознайомлення з текстом монографії. Сучасні когнітивні дослідження мають міждисциплінарний характер, тобто оперують інформацією з різних наукових сфер, а це формує певну зону викликів і ризиків, чого не оминула й дослідниця. Маємо на увазі використання термінів, закріплених за тією чи тією галуззю знань. Якщо такі терміни транспортують в інший предметний дискурс, то бажано подавати для них релевантну дефініцію, яка б ідентифікувала їх галузевий статус (у цьому разі лінгвістичний) і позбавила б контекст смислової неоднозначності. Тож авторці варто було б сформулювати визначення міжгалузевих термінів з урахуванням обраної лінгвістичної методології.

Загалом подана монографія є цілісним, структурно й змістовно переконливим дослідженням, виконаним в актуальній науковій площині, а отримані результати стануть органічною частиною сучасного досвіду вивчення й опису явищ і фактів російської мови.

\section{ЛІТЕРАТУРА}

1. Кубрякова Е. С. Язык и знание. Москва: Языки славянской культуры, 2004. $560 \mathrm{c}$.

\section{REFERENCES}

1. Kubryakova, E. S. (2004). Yazyk i znanie [Language and knowledge]. Moskva: Yazyki slavyanskoj kul'tury [in Russian].

Маленко Олена Олегівна - доктор філологічних наук, професор, завідувач кафедри українознавства і лінгводидактики, Харківський національний педагогічний університет імені Г. С. Сковороди. Вул. Валентинівська, 2, Харків, 61168, Україна.

Tel.: +38 067-938-86-57

E-mail: malena-o@yandex.ua

https://orcid.org/0000-0003-4753-0036

Malenko Olena Olehivna - Doctor of Philology, Professor, Head of the Ukrainian Studies and Applied Linguistics Department, H.S. Skovoroda Kharkiv National Pedagogical University. Valentynivska Str., 2, Kharkiv, 61168, Ukraine.

Надійшла до редакції 25 лютого 2020 року 